\title{
Correction to: Experimental investigation of biopolymer efficiency of double selective strain for oil extraction from petroleum reservoirs using microdeletion injection
}

\author{
Mohammad Reza Gharib ${ }^{1}$ Ali Heydari ${ }^{1}$ Payam Danesh ${ }^{2}$
}

๑) Springer-Verlag GmbH Germany, part of Springer Nature 2021

Correction to: Biomass Conversion and Biorefinery

https://doi.org/10.1007/s13399-021-01951-7

In this article, the figures were interchanged.

The original article has been corrected.

Publisher's note Springer Nature remains neutral with regard to jurisdictional claims in published maps and institutional affiliations.

The original article can be found online at https://doi.org/10.1007/ s13399-021-01951-7.

Mohammad Reza Gharib

m.gharib@torbath.ac.ir

1 Department of Mechanical Engineering, University of Torbat Heydarieh, Torbat Heydarieh, Iran

2 Department of Bio-Systems Engineering, University of Tehran, Tehran, Iran 